\title{
PENINGKATAN KEMAMPUAN PENALARAN MATEMATIS MAHASISWA CALON GURU MELALUI PEMBELAJARAN REFLEKTIF
}

Oleh:

\author{
Rohana \\ Pendidikan Matematika Jurusan PMIPA FKIP Universitas PGRI Palembang \\ rohana_pgri@yahoo.com
}

\begin{abstract}
ABSTRAK
Penelitian ini bertujuan untuk mengkaji peningkatan kemampuan penalaran matematis (KPM) melalui penerapan pembelajaran reflektif. Penelitian ini menggunakan metode kuasieksperimen dengan desain kelompok kontrol pretes dan postes nonekuivalen. Subyek penelitian ini adalah mahasiswa program studi pendidikan matematika pada salah satu Perguruan Tinggi Swasta di Palembang sebanyak 155 orang. Subyek penelitian dibedakan atas dua kelas yaitu kelas eksperimen yang mendapatkan pembelajaran reflektif (PR) dan kelas kontrol yang mendapatkan pembelajaran konvensional (PK). Penelitian dilaksanakan pada semester ganjil tahun akademik 2013/2014. Instrumen dalam penelitian ini adalah tes KPM, lembar observasi, dan pedoman wawancara. Dengan menggunakan uji Mann-Whitney diperoleh kesimpulan bahwa pencapaian dan peningkatan KPM mahasiswa calon guru yang mendapatkan PR lebih baik daripada mahasiswa calon guru yang mendapatkan PK.
\end{abstract}

Kata Kunci : Kemampuan penalaran matematis, pembelajaran reflektif

\begin{abstract}
This study aim to examine the enhancement of mathematical reasoning ability through application of reflective learning. This study use quasi-experiment method by non equivalent pretest and posttest control group design. Subject of this study are 155 students of mathematics education study program in one of Private Higher Education in Palembang. Subject of study is differentiated into two classes namely experiment class who get reflective learning and control class who get conventional learning. This study is conducted in odd semester academic year of 2013/2014. Instrument in this study are mathematical reasoning ability test, observation sheet, and interview guidance. By using Mann-Whitney test, the conclusion is obtained that mathematical reasoning ability achievement and enhancement of student teacher who get reflective learning is better than student teacher who get conventional learning.
\end{abstract}

Keywords: mathematical reasoning ability, reflective learning 


\section{PENDAHULUAN}

SDM yang mampu menghadapi tantangan di era informasi dan globalisasi ini adalah mereka yang memiliki kemampuan berfikir secara kritis, logis, sistematis, dan kreatif sehingga mampu menghadapi berbagai tantangan kehidupan secara mandiri dengan penuh rasa percaya diri (Suryadi, 2012:1). Hal tersebut tidak bisa lepas dari peran penting perkembangan matematika diberbagai disiplin ilmu. Namun, hasil tes Programme for International Student Assesment (PISA) 2012 dan Trends in International Mathematics and Science Study (TIMSS) 2011 menunjukkan bahwa mutu pembelajaran matematika di Indonesia tak kunjung membaik (Pranoto, 2013). Dampak dari rendahnya kemampuan berfikir ini dapat kita lihat melalui berbagai fenomena sosial di masyarakat seperti: kerusuhan sosial, perilaku merusak, sikap tak menghargai perbedaan, ketidakpatuhan pada hukum, dan sebagainya. Sebagaimana ditegaskan Pranoto (2013) bahwa apabila kemampuan berfikir matematis ini tak kunjung membaik dan dibiarkan berlarut-larut akan mengancam stabilitas negara dan keselarasan sosial yang didasarkan pada intelektualitas.

Matematika merupakan ilmu yang sarat dengan materi-materi yang dapat memicu berkembangnya kemampuan berfikir khususnya kemampuan penalaran. Hal ini dikarenakan matematika adalah ilmu yang mempunyai karakteristik deduktif aksiomatik, yang memerlukan kemampuan berfikir dan bernalar untuk memahaminya. Seperti yang dikemukakan oleh Tinggih (dalam Suherman dan Winataputra, 1992) bahwa matematika merupakan ilmu yang diperoleh dengan bernalar. Pernyataan tersebut dipertegas oleh Ansjar dan Sembiring (2000) bahwa penalaran merupakan karakteristik utama matematika yang tidak dapat dipisahkan dari kegiatan mempelajari dan mengembangkan matematika atau menyelesaikan suatu masalah matematika. Selain itu, Wahyudin (2008:35-36) menyatakan bahwa kemampuan penalaran sangat penting untuk memahami matematika dan bernalar secara matematis merupakan kebiasaan fikiran. Hasil penalaran ini kemudian dituangkan dalam konsep-konsep sistematis dalam matematika. Konsep-konsep ini terus berkembang menjadi konsep yang lebih kompleks dan maju bahkan dapat digunakan untuk memecahkan berbagai macam masalah dalam kehidupan.

Kemampuan penalaran ini berguna bagi seseorang dalam proses membangun dan membandingkan gagasan-gagasan dari beragam situasi yang dihadapi, sehingga ia dapat mengambil keputusan yang tepat dalam menyelesaikan permasalahan hidupnya. Seperti yang diungkapkan oleh Wahyudin (2008: 520), penalaran menawarkan cara-cara yang tangguh untuk membangun dan mengekspresikan gagasan-gagasan tentang beragam fenomena yang luas. Makin tinggi jenjang pendidikan seseorang, tentunya makin tinggi juga tingkat kesulitan pembelajaran matematikanya. Belajar matematika di tingkat perguruan tinggi umumnya melibatkan kemampuan kognitif tingkat tinggi, seperti kemampuan analisis, sintesis, dan evaluasi, bukan sekedar mengingat pengetahuan faktual ataupun aplikasi sederhana dari berbagai formula atau prinsip. 
Committee on the Undergraduate Program in Mathematics (CUPM) (MAA, 2004) memberikan enam rekomendasi dasar untuk jurusan, program dan semua mata kuliah dalam matematika. Salah satu rekomendasinya menerangkan bahwa setiap mata kuliah dalam matematika hendaknya merupakan aktivitas yang akan membantu mahasiswa dalam pengembangan daya analitis, penalaran kritis, pemecahan masalah dan kemampuan berkomunikasi. Berdasarkan rekomendasi CUPM tersebut, jelas bahwa kemampuan penalaran merupakan hal-hal yang perlu diperhatikan dalam pengajaran matematika khususnya di perguruan tinggi, tanpa mengesampingkan kemampuan-kemampuan lain tentunya. Terutama pada LPTK yang bertugas mendidik calon guru khususnya calon guru matematika, agar mempersiapkan mahasiswanya dalam memperkuat kemampuan penalaran.

Romberg \& Carpenter (Senger, 1999) meletakkan tanggungjawab keberhasilan reformasi dalam pendidikan matematika di pundak guru. Reformasi yang dimaksud salah satunya adalah menyangkut pendekatan atau model pembelajaran yang digunakan dalam pembelajaran matematika. Mengingat karakteristik matematika dengan kajian yang abstrak serta bersifat deduktif aksiomatik, tentu bukan suatu yang mudah bagi seorang calon guru untuk membelajarkan matematika kepada siswanya nanti. Oleh sebab itu, diperlukan suatu pendekatan atau model pembelajaran yangt mampu mengakomodasi kemampuan berfikir matematis mahasiswa calon guru khususnya kemampuan penalaran matematis. Hal ini dimaksudkan agar mahasiswa calon guru terlatih dalam menyelesaikan berbagai permasalahan dalam proses belajar mengajar di kelas nantinya.

Permasalahan yang dihadapi guru dalam pembelajaran di kelas menuntut guru untuk selalu berfikir, memberi perhatian serius, pertimbangan mendalam tentang kejadian atau keputusan yang diambil. Dalam membuat justifikasi tentang keputusan, guru tidak boleh bergantung kepada naluri atau teknik yang telah ditetapkan, sebaliknya guru perlu berfikir apakah yang sedang berlaku; apakah pilihan yang ada; dan lainlain pertanyaan yang berkaitan secara kritis dan analitis (Norlander-Case dalam Hussin \& Saleh, 2009). Keadaan ini bersesuaian dengan definisi pemikiran reflektif menurut Dewey (Hussin \& Saleh, 2009) yaitu "turning a subject over in the mind and giving it serious and consecutive consideration” Dalam konteks kajian ini, reflektif berarti berfikir dan meninjau kembali ide, perlakuan, dan situasi yang ada dalam proses belajar mengajar sebelum tindakan seterusnya diambil.

Reflective Learning merupakan pembelajaran dengan melibatkan kegiatan berfikir reflektif pada prosesnya. Refleksi dalam konteks pembelajaran dirumuskan Boud, et. all (dalam Sirajuddin, 2009; Kurnia, 2006) sebagai "a generic for those intellectual and affective activities in which individuals engage to explore their experiences in order to lead an new understanding and appreciations". Pada saat berfikir reflektif berlangsung pada seorang pebelajar, ia mempelajari apa yang sedang dihadapinya, berasumsi, menilai, bersikap, dan mengaplikasikan 
pemahamannya. Hal ini sangat baik sekali karena jika ini berlangsung secara terus menerus maka pada akhirnya kegiatan berfikir ini akan sampai pada pemahaman yang lebih mendalam, perubahan pemikiran, dan pada akhirnya menyelesaikan permasalahan. Hmelo \& Ferrari (Song, Koszalka,dan Grabowski, 2005) menyimpulkan lebih jauh bahwa refleksi membantu siswa/mahasiswa untuk membangun keterampilan berfikir tingkat tingginya.

Menurut Insuasty dan Castillo (2010), refleksi harus menjadi bagian yang mendasar bagi pengembangan guru karena guru memiliki kewajiban untuk mampu mengevaluasi dan menata kembali kemampuan mengajar agar dapat mengoptimalkan proses belajar-mengajar. Seorang guru reflektif juga diharuskan mampu untuk bersikap kritis terhadap kemampuan mengajarnya sendiri agar siswa bisa mendapatkan pengalaman belajar yang dinamis, yang berharga dan bermakna bagi kehidupan mereka. Lebih jauh Zeichner dan Liston dalam Radulescu (2013) menyatakan bahwa konsep pembelajaran reflektif sebagai sarana untuk mengembangkan kemampuan profesional guru. Hal tersebut dikarenakan konsep pembelajaran reflektif terdiri dari beberapa proses yang pada umumnya bertujuan menumbuhkan sikap eksplorasi dan penyelidikan sehingga mampu membangkitkan kesadaran calon guru serta menjadi faktor yang mempengaruhi proses pembelajaran calon guru.

Berpedoman pada latar belakang yang telah dikemukakan sebelumnya, permasalahan umum dalam penelitian ini adalah: "Apakah pembelajaran reflektif dapat meningkatkan kemampuan penalaran matematis mahasiswa calon guru?". Permasalahan umum tersebut diuraikan menjadi pertanyaan penelitian yaitu: "Apakah peningkatan kemampuan penalaran matematis mahasiswa calon guru yang mendapat pembelajaran reflektif lebih baik daripada mahasiswa calon guru yang mendapat pembelajaran konvensional?".

Adapun tujuan yang ingin dicapai pada penelitian ini adalah untuk mengkaji secara komprehensif peningkatan kemampuan penalaran matematis mahasiswa calon guru setelah mendapat pembelajaran reflektif dan pembelajaran konvensional.

\section{STUDI LITERATUR}

\section{Kemampuan Penalaran Matematis}

Kemampuan penalaran dapat dikembangkan melalui pembelajaran matematika. Kemampuan penalaran matematis adalah kemampuan memahami ide matematis secara lebih mendalam, mengamati data dan menggali ide yang tersirat, menyusun konjektur, analogi dan generalisasi, menalar secara logik. Baroody (1993:2-59) mengungkapkan ada empat alasan mengapa penalaran penting untuk matematika dan kehidupan sehari-hari, yaitu: 
1. The reasoning needed to do mathematics, penalaran diperlukan untuk mengerjakan matematika. Ini artinya penalaran berperan penting dalam pengembangan dan aplikasi matematika.

2. The need for reasoning in school mathematics, penalaran dibutuhkan dalam pelajaran matematika di sekolah. Hal ini jelas terlihat bahwa untuk menguasai konsep matematika dengan benar diperlukan penalaran dalam pembelajaran matematika.

3. Reasoning involved in other content area, artinya keterampilan-keterampilan penalaran dapat diterapkan pada ilmu-ilmu lainnya. Dapat dikatakan bahwa penalaran menunjang pengembangan ilmu lainnya.

4. Reasoning needed for everyday life, artinya penalaran berguna untuk kehidupan sehari-hari. Ini berarti penalaran berguna untuk mengatasi masalah dalam kehidupan sehari-hari.

Penalaran matematis merupakan proses pengambilan kesimpulan tentang sejumlah ide berdasarkan fakta-fakta yang ada melalui pemikiran yang logis dan kritis dalam menyelesaikan masalah matematika. Dalam NCTM (2000) penalaran matematis menjadi salah satu kemampuan yang diharapkan untuk dimiliki pebelajar dalam mempelajari matematika dan merupakan fondasi dalam memahami serta doing matematika. Penalaran matematis terjadi ketika pebelajar: 1) mengamati pola atau keteraturan, 2) merumuskan generalisasi dan konjektur berkenaan dengan keteraturan yang diamati, 3) menilai/menguji konjektur; 4) mengkonstruk dan menilai argumen matematika, dan 5) menggambarkan (menvalidasi) konklusi logis tentang sejumlah ide dan keterkaitannya (NCTM, 2000).

Jadi mengembangkan kemampuan penalaran dalam pembelajaran matematika menjadi penting karena akan berdampak dalam pemetaan nalar pebelajar terutama pada saat pengambilan keputusan ketika menyelesaikan permasalahan. Shadiq (2007) berpendapat bahwa seni bernalar dibutuhkan di setiap segi dan sisi kehidupan agar setiap warga bangsa dapat menunjukkan dan menganalisis masalah secara jernih, dapat memecahkan masalah dengan tepat, dapat menilai sesuatu secara kritis dan objektif, serta dapat mengemukakan pendapat maupun idenya serta runtut dan logis. Adapun kemampuan penalaran matematis dalam penelitian ini adalah kemampuan mahasiswa dalam: (1) menginterpretasikan suatu permasalahan berdasarkan konsep matematika terkait; (2) mengamati hubungan dari informasi yang diberikan dan dapat menyelesaikan masalah; (3) menarik analogi dari permasalahan yang serupa; (4) menganalisis dan membuat generalisasi dari permasalahan yang diberikan, dan (5) membuat keputusan dan menguji kebenaran rumus/jawaban yang diperoleh.

\section{Pembelajaran Reflektif}

Di dunia pendidikan, pembelajaran reflektif (reflektif learning) telah dikembangkan oleh banyak ahli pendidikan. sehingga cukup banyak variasi pembelajaran reflektif 
yang sampai kepada kita. Seperti yang diungkapkan oleh Poblete (1999) bahwa saat ini cukup sulit bagi kita untuk mendapatkan kejelasan definisi yang tepat mengenai mengajar reflektif dikarenakan terdapat begitu banyak perspektif dan konseptualisasi mengenai mengajar reflektif yang ditawarkan oleh banyak penulis yang berbeda.

Salah satu model pembelajaran reflektif adalah yang dirumuskan oleh The International Center for Jesuit Education (ICAJE) yaitu Paradigma Pedagogi Ignasian (Sirajuddin, 2009:195). Paradigma Pedagogi Ignasian (PPI) ini telah diaplikasikan pada sekolah-sekolah Ordo Jesuit di seluruh dunia (ICAJE, 1993). Menurut Drost (Sirajuddin, 2009) konsep berfikir reflektif melalui pembelajaran reflektif adalah inti dari PPI. Paradigma Pedagogi Ignatian (PPI) terdiri dari tiga unsur utama yaitu pengalaman (experience), refleksi (reflection), dan aksi (action). Sebagaimana dapat dilihat pada gambar di bawah ini.

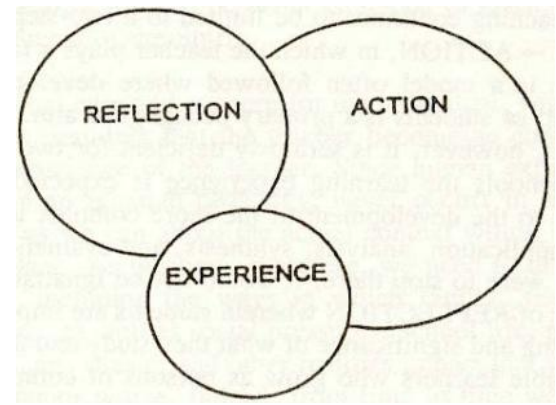

Gambar 1

Paradigma Ignasian

(Sumber: ICAJE, 1993:11)

Agar ketiga unsur tersebut dapat diaplikasikan dengan baik maka dibutuhkan sebuah unsur pra-pembelajaran (pre-learning element) yakni konteks (context) dan unsur pasca-pembelajaran (post-learning element) yakni evaluasi (evaluation). Sehingga dalam aplikasinya yang utuh, PPI diaplikasikan secara sistematis melalui lima langkah pembelajaran reflektif yaitu: 1) konteks (context); 2) pengalaman (experience); 3) refleksi (reflection); 4) aksi (action); dan 5) evaluasi (evaluation).

Pengenalan konteks (context) dapat dilakukan dosen pada saat apersepsi, dengan mengaitkan materi yang dipelajari dengan situasi dunia nyata, dan mendorong mahasiswa membuat hubungan antara pengetahuan yang dimiliki dengan penerapannya dalam kehidupan sehari-hari. Penyajian pengalaman (experience) dan Refleksi (reflection) diantaranya dapat dilakukan dalam diskusi kelompok atau presentasi. Pada tahap ini guru mengajukan pertanyaan-pertanyaan refleksi untuk melatih kepekaan mahasiswa terhadap implikasi dari materi yang sedang dipelajari. Aksi (action) merupakan pertumbuhan sikap dan tindakan yang ditampilkan mahasiswa berdasarkan pengalaman yang telah direfleksikan. Evaluasi (evaluation) dalam pembelajaran reflektif digunakan sebagai sarana untuk merefleksikan hasil 
belajar mahasiswa. Evaluasi tidak hanya berupa tes, ulangan atau ujian, perlu juga dilakukan dengan memberikan jurnal reflektif kepada mahasiswa untuk merekam dan mengomentari pengalaman mereka dalam pembelajaran.

Adapun langkah-langkah kegiatan pembelajaran dalam Pembelajaran Reflektif berbasis PPI yang diterapkan dalam penelitian adalah sebagai berikut.

\section{Fase Awal}

1) Dosen mengkondisikan suasana kelas agar siap mengikuti pembelajaran,

2) Dosen menjelaskan tujuan pembelajaran dan aktivitas yang diharapkan dilakukan mahasiswa pada proses pembelajaran.

3) Context. Dosen menyajikan topik pembelajaran sebagai pengetahuan baru yang akan dibahas, kemudian melakukan tanya jawab untuk mengecek pengetahuan prsyarat dan keterampilan yang dimiliki mahasiswa. Dosen juga mengarahkan mahasiswa melalui pertanyaan-pertanyaan yang memicu mahasiswa untuk mengaitkan pengetahuan awal mereka dengan topik yang akan dibahas.

\section{Fase Inti}

4) Mahasiswa dibagi dalam kelompok-kelompok kecil yang terdiri dari 4-5 orang dengan mempertimbangkan heterogenitas kemampuan mahasiswa.

5) Experience. Dosen memunculkan permasalahan baru berkaitan dengan topik yang akan dibahas dan disajikan dalam Lembar Kerja Mahasiswa (LKM). Hal ini dimaksudkan untuk merangsang mahasiswa memahami proses berfikir mereka sendiri. Dalam langkah ini, mahasiswa akan mencermati permasalahan yang muncul, berupaya untuk mempertajam masalah dan dapat mengidentifikasi strategi-strategi penyelesaian masalah, menggunakan strategi-strategi tersebut untuk menyelesaikan masalah, serta menentukan faktor-faktor yang diduga menyebabkan munculnya masalah.

6) Reflection. Dosen mengarahkan mahasiswa dan kelompoknya untuk dapat mencari berbagai informasi yang mendukung penyelesaian masalah (mengumpulkan data-data pendukung), merumuskan letak dan batasan masalah, serta penyelesaian masalah yang mungkin. Dosen sebagai fasilitator dan mediator dengan memberikan scaffolding bagi kelompok yang membutuhkan melalui pertanyaan-pertanyaan refleksi.

7) Dosen mengarahkan mahasiswa dan kelompoknya untuk belajar mencari strategi dalam menemukan proses penyelesaian dari permasalahan yang disajikan. Dalam langkah ini, mahasiswa mengembangkan berbagai kemungkinan dan solusi tentatif untuk menyelesaikan masalah, serta berusaha untuk dapat menyelesaikan masalah tersebut.

8) Apabila mahasiswa sudah dapat menemukan penyelesaian dari permasalahan yang dihadapi, dosen mengarahkan mahasiswa untuk dapat membuktikan solusi dari penyelesaian masalah yang telah ditemukan agar 
mereka dapat menarik suatu kesimpulan yang dapat dipertanggung jawabkan.

9) Action. Dosen memberikan kesempatan pada mahasiwa untuk mempresentasikan jawaban mereka dan sharing dalam diskusi kelas. Jawaban yang diajukan mahasiswa bukanlah hasil kesepakatan kelompok lagi karena mahasiswa boleh berbeda pendapat dengan kelompoknya. Selanjutnya dosen mengarahkan mahasiswa untuk dapat menerapkan hasil penyelesaian yang diperolehnya (pengetahuan baru yang diperoleh mahasiswa) pada situasi-situasi yang lain. Dalam hal ini, dosen dapat memberikan permasalah baru sebagai permasalahan lanjutan yang berkaitan dengan permasalahan yang telah diselesaikan oleh mahasiswa, agar mahasiswa selalu memodifikasi pemahaman yang telah dimilikinya (pengetahuan sebelumnya) dalam rangka menyelesaikan berbagai permasalahan baru.

\section{Fase Akhir}

10) Evaluation. Untuk mengetahui pencapaian mahasiswa secara individual terhadap topik yang telah dipelajari, dosen melakukan evaluasi dengan meminta mahasiswa menjawab beberapa pertanyaan. Selain itu, dosen juga meminta mahasiswa untuk menulis jurnal reflektif sebagai sarana latihan bagi mahasiswa agar dapat menilai dan memonitor keberhasilan proses belajarnya.

11) Dosen memberikan soal-soal untuk dikerjakan di rumah terkait materi yang sudah dipelajari. Selain itu dosen memberikan informasi materi yang akan dipelajari pada pertemuan yang akan datang, serta memberikan tugas ringkasan materi tersebut untuk dikerjakan di rumah.

\section{METODE PENELITIAN}

Penelitian ini merupakan penelitian eksperimen dengan tipe Quasi-Experimental (Ruseffendi, 2005; Sugiyono, 2009; Sukmadinata, 2008). Desain eksperimen yang digunakan adalah desain kelompok kontrol pretes dan postes nonekuivalen atau Nonequivalent Pre-Test and Post-Test Control- Group Design (Creswell, 2012; Sugiyono, 2009). Secara singkat, desain eksperimen tersebut, dapat digambarkan sebagai berikut.

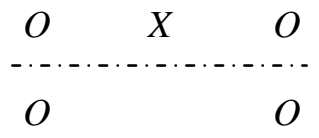

Keterangan:

$\begin{array}{ll}O & : \text { pretes/postes KPM } \\ X & : \text { Pembelajaran Reflektif (Reflective Learning) }\end{array}$

Subjek penelitian ini adalah mahasiswa semester ganjil tahun akademik 2013/2014 di Program Studi Pendidikan Matematika Fakultas Keguruan dan Ilmu Pendidikan tingkat strata 1, pada salah satu perguruan tinggi swasta (PTS) kota Palembang. 
Subjek penelitian berjumlah 155 orang mahasiswa yang terdiri dari 4 kelas paralel. Dua kelas sebagai kelas eksperimen (79 orang), sedangkan dua kelas lainnya sebagai kelas kontrol (76 orang). Sebelum dilakukan penelitian keempat kelas ini terlebih dahulu diuji kesetaraannya. Pemilihan kelas eksperimen dan kelas kontrol dilakukan secara acak kelas.

Instrumen tes KPM yang digunakan sudah diuji validitas, reliabilitas, daya pembeda dan tingkat kesukarannya. Soal tes dinyatakan telah memenuhi karakteristik yang memadai untuk digunakan dalam penelitian.

\section{HASIL PENELITIAN DAN PEMBAHASAN}

\section{Hasil Analisis Data}

Data KPM dikumpulkan dan dianalisis untuk mengetahui KPM mahasiswa sebelum dan sesudah pemberian perlakuan. Untuk memperoleh gambaran kualitas KPM mahasiswa, data dianalisis secara deskriptif agar diketahui rerata dan simpangan baku skor pretes, postes, dan n-gain KPM mahasiswa. Statistik deskriptif data KPM mahasiswa selengkapnya disajikan pada Tabel 1 di bawah ini.

\section{Tabel 1}

Statistik Deskriptif Data KPM

\begin{tabular}{|c|c|c|c|c|c|c|c|c|}
\hline \multirow{2}{*}{ Pembelajaran } & \multirow{2}{*}{$n$} & \multicolumn{2}{|c|}{ Pretes } & \multicolumn{2}{c|}{ Postes } & \multicolumn{2}{c|}{ N-Gain } & \multirow{2}{*}{$\begin{array}{c}\text { Kategori } \\
\text { N-Gain }\end{array}$} \\
\cline { 3 - 9 } & & $\bar{x}$ & $s$ & $\bar{x}$ & $s$ & $\bar{x}$ & $s$ & Sedang \\
\hline PR & 79 & 7,14 & 2,19 & 29,58 & 7,91 & 0,55 & 0,18 & Sedang \\
\hline PK & 76 & 7,12 & 1,83 & 20,89 & 9,07 & 0,34 & 0,22 & Sedang \\
\hline
\end{tabular}

Keterangan: Skor Maksimal Ideal 48

Berdasarkan Tabel 1 tampak bahwa rerata pencapaian dan peningkatan KPM mahasiswa yang mendapat pembelajaran reflektif (PR) lebih tinggi daripada mahasiswa yang mendapat pembelajaran konvensional (PK). Selanjutnya dilakukan analisis data pretes KPM untuk mengetahui bahwa sebelum diberikan perlakuan pembelajaran yang berbeda, kedua kelompok (eksperimen dan kontrol) mempunyai KPM yang sama atau berbeda. Berikut ringkasan hasil uji statistik data pretes KPM.

Tabel 2

Ringkasan Uji Statistik Data Pretes KPM

\begin{tabular}{|c|c|c|c|c|c|c|}
\hline \multirow{2}{*}{ Pembelajaran } & \multirow[b]{2}{*}{$n$} & \multicolumn{2}{|c|}{ Pretes } & \multirow{2}{*}{ Uji Normalitas } & \multirow{2}{*}{$\begin{array}{c}\text { Uji Perbedaan } \\
\text { Rerata }\end{array}$} & \multirow[b]{2}{*}{ Interpretasi } \\
\hline & & $\overline{x^{2}}$ & $s$ & & & \\
\hline PR & 79 & 7,14 & 2,19 & $\begin{array}{c}\text { Tidak berdistribusi } \\
\text { normal }\end{array}$ & \multirow[b]{2}{*}{$\mathrm{H}_{0}$ diterima } & \multirow[b]{2}{*}{$\begin{array}{l}\text { Tidak ada } \\
\text { perbedaan }\end{array}$} \\
\hline PK & 76 & 7,12 & 1,83 & $\begin{array}{c}\text { Tidak berdistribusi } \\
\text { normal }\end{array}$ & & \\
\hline
\end{tabular}

Keterangan: $\alpha=0,05$ 
Dari Tabel 2 diketahui data pretes KPM tidak berdistribusi normal, sehingga dilanjutkan dengan uji statistik non parametrik yaitu uji Mann-Whitney. Hasil menunjukkan hipotesis nol diterima. Hal ini berarti, tidak ada perbedaan yang signifikan antara rerata data pretes KPM mahasiswa yang mendapat PR dan mahasiswa yang mendapat PK. Hasil ini memberikan kesimpulan bahwa sebelum diberikan perlakuan yang berbeda antara kelas eksperimen yang mendapatkan PR dan kelas kontrol yang mendapatkan PK, kedua kelompok mahasiswa tersebut mempunyai KPM yang relatif sama pada taraf signifikansi $\alpha=0,05$.

Tabel 3

Ringkasan Uji Statistik Data Postes KPM

\begin{tabular}{|c|c|c|c|c|c|c|}
\hline \multirow{2}{*}{ Pembelajaran } & \multirow{2}{*}{$n$} & \multicolumn{2}{|c|}{ Postes } & Uji Normalitas & $\begin{array}{c}\text { Uji Perbedaan } \\
\text { Rerata }\end{array}$ & Interpretasi \\
\cline { 3 - 4 } PR & 79 & 29,58 & 7,91 & $\begin{array}{c}\text { Tidak } \\
\text { berdistribusi } \\
\text { normal }\end{array}$ & \multirow{2}{*}{$\mathrm{H}_{0}$ ditolak } & $\begin{array}{c}\text { Ada } \\
\text { perbedaan }\end{array}$ \\
\hline PK & 76 & 20,89 & 9,07 & $\begin{array}{c}\text { Tidak } \\
\text { berdistribusi } \\
\text { normal }\end{array}$ & \\
\hline
\end{tabular}

Keterangan: $\alpha=0,05$

Hasil uji Mann-Whitney U pada Tabel 3 di atas menunjukkan bahwa terdapat perbedaan yang signifikan antara rerata data pencapaian KPM mahasiswa yang mendapatkan PR dengan mahasiswa yang mendapatkan PK. Dengan memperhatikan hasil perhitungan statistik deskriptif data pencapaian KPM pada Tabel 1 yang menunjukkan bahwa rerata pencapaian KPM mahasiswa yang mendapatkan PR lebih tinggi daripada mahasiswa yang mendapat PK, dapat disimpulkan bahwa pencapaian KPM mahasiswa yang mendapat PR lebih baik daripada mahasiswa yang mendapat PK.

Tabel 4

Ringkasan Uji Statistik Data N-Gain KPM

\begin{tabular}{|c|c|c|c|c|c|c|}
\hline \multirow{2}{*}{ Pembelajaran } & $n$ & \multicolumn{2}{|c|}{ N-Gain } & \multirow{2}{*}{ Uji Normalitas } & $\begin{array}{c}\text { Uji Perbedaan } \\
\text { Rerata }\end{array}$ & Interpretasi \\
\cline { 3 - 4 } & $\bar{x}$ & $s$ & & Tidak & \\
PR & 79 & 0,55 & 0,18 & $\begin{array}{c}\text { Terdistribusi } \\
\text { normal }\end{array}$ & \multirow{2}{*}{$\mathrm{H}_{0}$ ditolak } & $\begin{array}{c}\text { Ada } \\
\text { perbedaan }\end{array}$ \\
\hline PK & 76 & 0,34 & 0,22 & $\begin{array}{c}\text { Tidak } \\
\text { berdistribusi } \\
\text { normal }\end{array}$ & \\
\hline
\end{tabular}

Keterangan: $\alpha=0,05$

Dari Tabel 4 terlihat bahwa hipotesis nol ditolak. Ini berarti bahwa data peningkatan KPM berdasarkan kelompok pembelajaran berbeda secara signifikan pada taraf signifikansi $\alpha=0,05$. Dengan memperhatikan nilai rerata kedua kelompok tersebut dapat disimpulkan bahwa peningkatan KPM mahasiswa calon guru yang mendapat PR lebih baik daripada mahasiswa calon guru yang mendapat PK. 


\section{Pembahasan}

Hasil penelitian telah menunjukkan bahwa pembelajaran reflektif memberikan pengaruh positif yang signifikan terhadap pencapaian dan peningkatan kemampuan penalaran matematis mahasiswa calon guru. Berdasarkan temuan-temuan penelitian ini dapat dinyatakan bahwa faktor pembelajaran memberikan pengaruh terhadap aktivitas mahasiswa di kelas selama mengikuti proses pembelajaran. Dengan kata lain, hasil penelitian ini menunjukkan bahwa pembelajaran reflektif secara signifikan lebih baik dalam meningkatkan kemampuan penalaran matematis. Hasil temuan ini memperkuat dan melengkapi hasil-hasil penelitian terdahulu tentang pembelajaran reflektif antara lain penelitian yang dilakukan oleh Nainggolan (2011), Lasmanawati (2011), dan Zulmaulida (2012) yang menyimpulkan bahwa pembelajaran reflektif lebih baik daripada pembelajaran konvensional dalam meningkatkan kemampuan matematis maupun berpikir matematis pada siswa sekolah dasar, siswa sekolah menengah dan mahasiswa perguruan tinggi.

Berdasarkan karakteristik antara pembelajaran reflektif dan pembelajaran konvensional, sudah sewajarnya jika terjadi perbedaan hasil kemampuan yang diperoleh mahasiswa setelah mengikuti pembelajaran. Pada pembelajaran reflektif, mahasiswa dilatih dan dibiasakan berfikir matematis melalui soal-soal pemecahan masalah, serta pertanyaan-pertanyaan refleksi dari dosen maupun bahan ajar. Dengan demikian, mahasiswa akan terampil dalam mengumpulkan informasi yang relevan, menganalisis informasi, dan menyadari betapa pentingnya menguji kembali hasil yang telah diperolehnya. Pada akhirnya mahasiswa akan memiliki kemampuan mengambil keputusan yang merupakan bagian dari indikator penalaran matematis. Sebagaimana ditegaskan oleh Conney (dalam Hudojo, 1988:119) bahwa mengajarkan penyelesaian masalah kepada pebelajar memungkinkan mereka menjadi lebih analitik di dalam mengambil keputusan di dalam hidupnya.

Mahasiswa diberi kesempatan untuk berperan aktif dalam proses pembelajaran, khususnya saat melakukan diskusi (diskusi kelompok dan diskusi kelas). Mahasiswa mengorganisasi ide-ide dan pengetahuan yang mereka miliki terkait dengan masalah, selain itu mahasiswa dapat mengajukan pertanyaan atau isu-isu sekitar masalah. Selanjutnya mahasiswa diberi kesempatan untuk menyatakan apa yang mereka pahami dan tidak pahami. Saat diskusi kelompok berlangsung, dosen berkeliling kelas memperhatikan diskusi yang terjadi. Apabila diperlukan, dosen sebagai fasilitator dapat memberikan petunjuk atau scaffolding kepada mahasiswa untuk membuat keterkaitan antara konsep-konsep dan prosedur-prosedur matematis. Scaffolding yang diberikan dosen berupa pertanyaan-pertanyaan reflektif yang bersifat membantu mahasiswa ketika mengalami kesulitan dalam menyelesaikan masalah. Hal ini bersesuaian dengan pernyataan Baig dan Anjun (2006) bahwa suasana kelas yang bersahabat sangat mendukung peningkatan kemampuan 
penalaran pebelajar, karena pebelajar akan berpendapat, mengajukan pertanyaan dan menggambarkan pemikirannya tanpa ragu-ragu.

Penulisan jurnal reflektif diakhir pembelajaran, mampu merekam hubunganhubungan dan makna-makna yang diperoleh mahasiswa saat proses pembelajaran, sehingga membantu mahasiswa menyatukan proses refleksi yang telah dilakukan. Sebagaimana diungkapkan Coughlan (2007) bahwa jurnal reflektif (reflective journal) digunakan pebelajar untuk mencatat kemajuan studinya yang membantu mereka menemukan strategi belajarnya sekaligus sebagai evaluasi kinerja pebelajar. Lebih lanjut Coughlan (2007) menyatakan bahwa berfikir dan menulis merupakan proses yang tidak dapat dipisahkan, menulis secara reflektif berarti secara tidak langsung menuntun kita untuk berfikir tentang proses berfikir kita sendiri atau dikenal dengan istilah 'metakognisi'. Sebagaimana yang dikemukakan Sternberg (1999) bahwa aktivitas metakognisi merupakan bagian dari aspek penalaran matematis.

Keunggulan dari pembelajaran reflektif lainnya adalah model pembelajaran ini mampu memfasilitasi aspek kognitif dan aspek afektif secara bersamaan (ICAJE, 1993). Hal ini terlihat saat proses pembelajaran berlangsung, mahasiswa saling menghormati dan berpandangan positif serta peka kepada anggota lain. Mahasiswa saling menghargai ketika melaksanakan pembelajaran, memberi kesempatan secara bergiliran saat mengajukan dan menjawab pertanyaan ketika berdiskusi baik dalam kelompok, diskusi kelas, atau ketika mempresentasikan hasil diskusi di depan kelas.

Berbeda halnya pada pendekatan pembelajaran konvensional, dosen merupakan model, pusat kegiatan proses pembelajaran, sumber pengetahuan, dan kurang melibatkan mahasiswa secara aktif dalam kegiatan pembelajaran. Dosen menjelaskan materi secara terperinci, dilanjutkan dengan memberikan contoh dan cara menyelesaikan soal. Mahasiswa memperhatikan penjelasan dosen, kemudian mencatat apa yang dijelaskan dosen. Sebelum mahasiswa mencatat, biasanya dosen memberi waktu kepada mahasiswa untuk bertanya mengenai hal-hal yang belum dipahami. Jika ada mahasiswa yang bertanya, dosen langsung menjelaskan secara klasikal. Selanjutnya dosen memberikan soal-soal latihan yang dikerjakan secara individu, dengan berkeliling kelas dosen memperhatikan cara mahasiswa mengerjakan soal latihan, dan sesekali membantu mengarahkan mahasiswa yang mengalami kesulitan. Setelah waktu untuk mengerjakan soal habis, semua mahasiswa mengumpulkan hasil pekerjaannya untuk dinilai dosen. Saat pembahasan, beberapa mahasiswa diminta mengerjakan soal di papan tulis. Meskipun dalam pembelajaran konvensional juga terjadi tanya jawab, tetapi hanya terjadi komunikasi dua arah yang melibatkan antara dosen dan mahasiswa. Proses pembelajaran ini seperti ini tidak mengkondisikan terjadinya komunikasi multi arah, sehingga pembelajaran terkesan pasif. Jika pun ada yang bertanya atau maju untuk mempresentasikan, biasanya mahasiswa yang itu-itu saja. Soal-soal rutin yang diberikan dalam pembelajaran maupun latihan di rumah membuat mahasiswa 
kurang mengembangkan potensi berpikirnya dan merasa tidak tertantang untuk menggali materi lebih jauh. Dalam hal ini, mahasiswa beranggapan bahwa belajar adalah mengikuti petunjuk dosen, tidak perlu kreatif, dan yang penting semua yang disampaikan dosen dikuasai. Selain itu, dalam pembelajaran konvensional mahasiswa tidak dilatih untuk melakukan refleksi terhadap pembelajarannya. Akibatnya, mahasiswa kurang mampu menyelesaikan masalah-masalah yang lebih menantang dan membutuhkan proses berpikir tingkat tinggi seperti penalaran matematis.

\section{KESIMPULAN DAN SARAN}

\section{Kesimpulan}

Berdasarkan rumusan masalah, hasil penelitian, dan pembahasan seperti yang telah dikemukakan sebelumnya, diperoleh simpulan bahwa pencapaian dan peningkatan kemampuan penalaran matematis mahasiswa calon guru yang mendapat pembelajaran reflektif lebih baik daripada mahasiswa calon guru yang mendapat pembelajaran konvensional. Peningkatan kemampuan penalaran matematis mahasiswa calon guru yang mendapat PR dan PK tergolong sedang. Pencapaian kemampuan penalaran matematis mahasiswa calon guru yang mendapat PR tergolong cukup, sedangkan mahasiswa calon guru yang mendapat PK tergolong kurang.

\section{Saran}

a. Hasil penelitian ini menunjukkan bahwa kemampuan penalaran matematis mahasiswa kurang berkembang baik pada pembelajaran konvensional. Oleh karena itu, disarankan bagi para dosen untuk menerapkan pembelajaran non konvensional yang berbasis konstruktivisme dalam mengembangkan kemampuan berfikir matematis khususnya pada kemampuan penalaran matematis. Pembelajaran reflektif sebaiknya dijadikan alternatif model pembelajaran.

b. Hasil penelitian ini kurang mencapai hasil yang optimal, terlihat pada rerata pencapaian kemampuan penalaran matematis mahasiswa, masih tergolong cukup, sementara peningkatannya tergolong sedang. Bagi peneliti lain ataupun dosen yang akan menerapkan pembelajaran reflektif disarankan untuk: a) memberikan cukup waktu bagi mahasiswa untuk bekerja mandiri sebelum masuk pada kegiatan diskusi; b) pengelolaan dan setting kelas yang kondusif sehingga mobilitas dosen dalam berinteraksi dengan mahasiswa lebih merata; c) dosen harus jeli dan bijak dalam menanggapi jurnal reflektif mahasiswa.

c. Proses belajar dalam pembelajaran reflektif memicu situasi didaktis yang kompleks sehingga menuntut dosen/guru tanggap terhadap situasi didaktis yang dihadapi, mampu melakukan tindakan didaktis yang bervariasi (misalnya dalam memberikan scaffolding atau pertanyaan-pertanyaan reflektif), mampu 
mengakomodasi berbagai respon pebelajar/mahasiswa, dan sekaligus mampu me-manage waktu pembelajaran dengan baik.

d. Peneliti lain disarankan mengoptimalkan fungsi jurnal reflektif dalam mengevaluasi progress kemampuan berfikir mahasiswa di akhir semester melalui tugas proyek atau portfolio

\section{DAFTAR PUSTAKA}

Ansjar, M. \& Sembiring (2000). Hakikat Pembelajaran MIPA dan Kiat Pembelajaran Matematika di Perguruan Tinggi. Jakarta: Dirjen Dikti Departemen Pendidikan Nasional.

Baig, S. dan Anjun H. (2006). "Learning Mathematical Rules with Reasoning". Eurasia Journal of Mathematics, Science and Technology Education. 2, (2), 15-39.

Baroody, A.J. (1993) Problem Solving, Reasoning, and Communicating, K-8 (Helping Children Think Mathematically). New York : Macmillan Publishing Company.

Coughlan, A. (2007). Reflective Learning: Keeping A Reflective Learning Journal. DCU Student Learning Resources.

Creswell. (2009). Research Design Pendekatan Kualitatif, Kuantitatif, dan Mixed Edisi Ketiga. Yogyakarta: Pustaka Pelajar.

Hudojo, H. (1988). Mengajar Belajar Matematika. Jakarta: Dirjen Dikti-Depdikbud

Hussin, Z. \& Saleh, F. (2009). Amalan Reflektif dalam Pengajaran Matematik: Satu Kajian Kes. Dalam Jurnal Pendidikan Islam Jilid 13 Bil 2 Julai 2009 / Rejab 1430 [Online]. Tersedia: http://i-epistemology.net/e-journal/jurnalpendidikan-islam/1128-jurnal-pendidikan-islam.html. [20 Januari 2013].

ICAJE,The International Centre for Jesuit Education in Rome. (1993). Ignatian Pedagogy: A Practical Approach. [Online]. Tersedia: http://www.rockhurst .edu/media/filer_private/uploads/ignatian_pedagogy_a_practical_approach.pd f. [27 Desember 2013].

Insuasty, E.A. dan Castillo, L.C.Z. (2010). Exploring Reflective Teaching through Informed Journal Keeping and Blog Group Discussion in the Teaching Practicum. PROFILE: Issues in Teachers'Professional Development Vol.12 No.2, October 2010. ISSN 1657-0790. Bogotá, Columbia. Pages $87-$ 105.

Kurnia, I. (2006). Pengembangan Model Pembelajaran untuk Meningkatkan Kemampuan Reflektif Mahasiswa S1-PGSD pada Mata Kuliah Penelitian Tindakan Kelas. Disertasi Pengembangan Kurikulum SPS UPI.

Lasmanawati, A. (2011). Pengaruh Pembelajaran Menggunakan Pendekatan Proses Berpikir Reflektif terhadap Peningkatan Kemampuan Koneksi dan Berpikir Kritis Matematis Siswa. Tesis Pendidikan Matematika SPS UPI. 
Mathematics Association of America. (2004). Undergraduate Programs and Courses in the Mathematical Sciences: CUPM Curriculum Guide 2004. Washington DC: The Mathematics Association of America Published.

Nainggolan, L. (2011). Model Pembelajaran Reflektif untuk Meningkatkan Pemahaman Konsep dan Kemampuan Komunikasi Matematis. Tesis Pendidikan Matematika SPS UPI.

NCTM. (2000). Principles and Standards for School Mathematics. Reston, Virginia: NCTM.

Poblete, D.P. (1999). A Reflective Teaching Model: An Adventist Assessment. Prepared for the $24^{\text {th }}$ International Faith and Learning Seminar Held at Andrews University, Berrien Springs, Michigan, U.S.A.

Pranoto, I. (2013). Kasmaran Bermatematika. Dalam Harian Kompas diterbitkan Kamis, 26 Desember 2013.

Radulescu, C. (2013). Reinventing Reflective Learning Methods in Teacher Education. Procedia - Social and Behavioral Sciences 78 (2013) $11-15$.

Ruseffendi, E.T. (2005). Dasar-dasar Penelitian Pendidikan dan Bidang Noneksakta Lainnya. Bandung: Tarsito.

Senger, E.S. (1999). Reflective reform in Mathematics: The recursive nature of teacher change. Educational Studies in Mathematics, 37, 199-221.

Sirajuddin (2009). Model Pembelajaran Reflektif: Suatu Model Belajar Berbasis Pengalaman. Dalam Didaktika Jurnal Kependidikan Vol 4 No.2 hal 189-200.

Song, H.D., Koszalka, T. A., dan Grabowski, B. (2005). Exploring Instructional Design Factors Prompting Reflective Thinking in Young Adolescents. In Canadian Journal of Learning and Technology, Vol 31, No. 2, 49-68.

Shadiq, F. (2007). Penalaran atau Reasoning, Mengapa Perlu Dipelajari Para Siswa di Sekolah?. [Online]. Tersedia: https://fadjarp3g.files.wordpress.com/2007/09/ ok-penalaran_gerbang_.pdf. [19 Januari 2015].

Sternberg, R. J. (1999). The Nature of Mathematical Reasoning dalam Lee V. Stiff dan Frances R. Curcio (edt) Developing Mathematical Reasoning in Grades K-12, 37-44. Virginia: NCTM.

Sugiyono (2009). Metode Penelitian Pendidikan. Bandung : CV. Alfabeta.

Suherman,E. \& Winataputra, U. (1992). Strategi Belajar Mengajar Matematika, Jakarta: Penerbit Universitas Terbuka.

Sukmadinata, N.S. (2008). Metode Penelitian Pendidikan. Bandung: Remaja Rosdakarya.

Suryadi, D. (2012). Membangun Budaya Baru dalam Berpikir Matematika. Bandung: Rizqi Press.

Wahyudin (2008). Pembelajaran dan Model-Model Pembelajaran. Bandung: UPI

Zulmaulida, Rahmy. (2012). Pengaruh Pembelajaran dengan Pendekatan Proses Berpikir Reflektif terhadap Peningkatan Kemampuan Koneksi dan Berpikir Kritis Matematis Siswa. Tesis Pendidikan Matematika SPS UPI. 